\title{
Dietary nutrients associated with preservation of lung function in Hispanic and non-Hispanic white smokers from New Mexico
}

This article was published in the following Dove Press journal:

International Journal of COPD

30 October 2017

Number of times this article has been viewed

\author{
Shuguang Leng ${ }^{1,2}$ \\ Maria A Picchi' \\ Yohannes Tesfaigzi ${ }^{3}$ \\ Guodong Wu' \\ W James Gauderman ${ }^{4}$ \\ Fadi $\mathrm{Xu}^{5}$ \\ Frank D Gilliland ${ }^{4}$ \\ Steven A Belinsky',2,6 \\ 'The Lung Cancer Program, \\ Lovelace Respiratory Research \\ Institute, ${ }^{2}$ Cancer Control Research \\ Program, University of New \\ Mexico Comprehensive Cancer \\ Center, ${ }^{3}$ COPD Program, Lovelace \\ Respiratory Research Institute, \\ Albuquerque, NM, ${ }^{4}$ Keck School of \\ Medicine, University of Southern \\ California, Los Angeles, CA, \\ ${ }^{5}$ Pathophysiology Program, Lovelace \\ Respiratory Research Institute, \\ ${ }^{6}$ Cancer Genetics and Epigenetics \\ Program, University of New Mexico \\ Comprehensive Cancer Center, \\ Albuquerque, NM, USA
}

Background: COPD is the third leading cause of death in the United States. Cigarette smoking accelerates the age-related forced expiratory volume in $1 \mathrm{~s}\left(\mathrm{FEV}_{1}\right)$ decline, an important determinant for the genesis of COPD. Hispanic smokers have lower COPD prevalence and FEV decline than non-Hispanic whites (NHWs).

Patients and methods: A nutritional epidemiological study was conducted in the Lovelace Smokers cohort (LSC; $n=1,829)$ and the Veterans Smokers cohort $(n=508)$ to identify dietary nutrients $(\mathrm{n}=139)$ associated with average $\mathrm{FEV}_{1}$ and its decline and to assess whether nutrient intakes could explain ethnic disparity in $\mathrm{FEV}_{1}$ decline between Hispanics and NHW smokers. Results: Nutrients discovered and replicated to be significantly associated with better average $\mathrm{FEV}_{1}$ included magnesium, folate, niacin, vitamins A and D, eicosenoic fatty acid (20:1n9), eicosapentaenoic acid (20:5n3), docosapentaenoic acid (DPA; 22:5n3), docosahexaenoic acid (22:6n3), and fiber. In addition, greater intakes of eicosenoic fatty acid and DPA were associated with slower $\mathrm{FEV}_{1}$ decline in the LSC. Among omega 3 polyunsaturated fatty acids, DPA is the most potent nutrient associated with better average $\mathrm{FEV}_{1}$ and slower $\mathrm{FEV}_{1}$ decline. Adverse effect of continuous current smoking on $\mathrm{FEV}_{1}$ decline was completely negated in LSC members with high DPA intake ( $>20 \mathrm{mg}$ /day). Slower FEV decline in Hispanics compared to NHWs may be due to the greater protection of eicosenoic fatty acid and DPA for FEV 1 decline rather than greater intake of protective nutrients in this ethnic group.

Conclusion: The protective nutrients for the preservation of $\mathrm{FEV}_{1}$ in ever smokers could lay foundation for designing individualized nutritional intervention targeting "optimal physiological levels" in human to improve lung function in ever smokers. Ethnic disparity in FEV decline may be explained by difference in magnitude of protection of dietary intakes of eicosenoic fatty acid and DPA between Hispanics and NHWs.

Keywords: nutrientomics, spirometry, ethnic disparity

\section{Background}

COPD, characterized by a progressive and partially irreversible airflow limitation, is the third leading cause of death in the United States. Cigarette smoking, exposure to secondhand smoke, bacterial and viral infections, and indoor and outdoor air pollutants, are common risk factors, which may affect the maximally attained forced expiratory

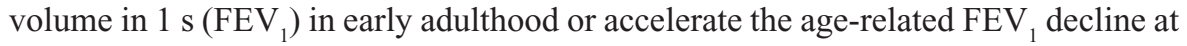
older age, two important determinants in the genesis of COPD. ${ }^{1-3}$ Several dietary factors and patterns may be protective for obstructive lung diseases. Using cross-sectional or case-control designs, candidate dietary nutrients and food items including vitamins A, $\mathrm{C}$, and $\mathrm{E}, \beta$-carotene, omega 3 polyunsaturated fatty acids (n-3 PUFAs), magnesium,
Correspondence: Shuguang Leng; Steven A Belinsky

The Lung Cancer Program, Lovelace Respiratory Research Institute, 2425 Ridgecrest Drive SE, Albuquerque, NM 87I08, USA

Tel +I $5053489160 ;+$ I 5053489465

$\mathrm{Fax}+\mathrm{I} 5053484990$

Email sleng@LRRI.org;

sbelinsk@LRRI.org

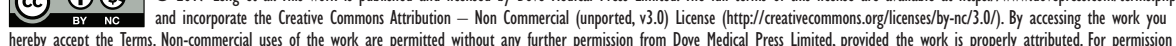
hereby accept the Terms. Non-commercial uses of the work are permitted without any further permission from Dove Medical Press Limited, provided the work is properly attributed. For permission 
dietary fiber, and hard fruit such as apple were associated with better $\mathrm{FEV}_{1}$ or lower prevalence of COPD. ${ }^{4-6} \mathrm{~A}$ few studies collected longitudinal spirometry data and identified greater intake of vitamin $\mathrm{C}$ and fresh fruit and serum carotenoids at baseline or increased consumption or level over time as being associated with slower $\mathrm{FEV}_{1}$ decline, although the results were inconsistent. ${ }^{7-12}$ In addition, a prudent diet rich in fruit, vegetables, whole-meal cereals, and fish was inversely associated with prevalent COPD. ${ }^{9,13-15}$

New Mexico (NM) has the highest percentage (47\%) of Hispanics of any state with the majority of Hispanics born in the United States. ${ }^{16}$ The ancestry of NM Hispanics is mainly composed of $63 \%$ European and 35\% Native American ancestry. ${ }^{1,17}$ NM Hispanic smokers have lower prevalence of COPD compared to non-Hispanic whites (NHWs) that may be attributed to lower exposure to cigarette smoke,

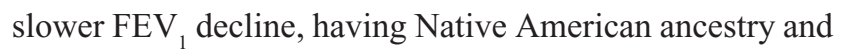
protective sequence variants that are polymorphic only in Hispanics. ${ }^{1,18,19}$ The effect of dietary intakes on this ethnic disparity has never been explored before.

In this study, we used the validated Harvard food frequency questionnaire (FFQ) to assess dietary intake of 139 nutrients at study entry in current and former smokers from the Lovelace Smokers cohort (LSC; n=1,829) and the Veteran Smokers cohort (VSC; $\mathrm{n}=508$ ). Protective dietary nutrients associated with better $\mathrm{FEV}_{1}$ were discovered in the LSC and replicated in the VSC. We further assessed whether the nutrients associated with better $\mathrm{FEV}_{1}$ had any effect on age-related $\mathrm{FEV}_{1}$ decline in the LSC due to the availability of longitudinal spirometry data. Finally, the ethnic disparity of dietary intake of protective nutrients and their potential contribution to the ethnic disparity of $\mathrm{FEV}_{1}$ decline were explored in 327 Hispanics and 1,502 NHWs in the LSC.

\section{Methods}

\section{LSC and VSC}

Enrollment in the LSC started in 2001 with the goal to conduct longitudinal studies on biomarkers of respiratory diseases, including COPD and lung cancer in biospecimens from smokers. ${ }^{20}$ Enrollment was restricted to current and former smokers aged 40-74 years with a minimum of 10 pack-years of smoking. Cohort members returned approximately every 18 months, and a spirometry test was conducted at every visit by certified and registered respiratory therapists strictly adhering to the 1994 American Thoracic Society guidelines. ${ }^{21}$ The VSC began recruitment of smokers in 2000 with enrollment criteria similar to the LSC except that most VSC participants were males (96.7\%) and had smoked at least 100 cigarettes during their life time. All participants signed a consent form written in English, and the institutional review boards of the Lovelace Respiratory Research Institute (Western institutional review board) and New Mexico Veteran Health Care System approved all investigations using human tissues and clinical data.

\section{Baseline dietary assessment}

The English version of the validated Harvard semiquantitative FFQ was completed at study entry. ${ }^{22}$ The FFQ collects the consumption frequency and serving size for $\sim 150$ food items over the previous 12 months and has excellent coverage for food items of the US Southwestern style. ${ }^{23}$ Daily estimates of the nutrient intakes are derived by summing over all foods, the products of the reported frequency of each food by the amount of nutrient in a specified (or assumed) serving of that food, based primarily on US Department of Agriculture publications. ${ }^{22}$ The applicability of this FFQ in New Mexicans is further introduced in Supplementary material. This study focused on 139 nutrients with $<40 \%$ missing rate in 1,829 LSC and 508 VSC members. A convenient set of 28 LSC cohort members filled the FFQ for a second time at follow-up visits $\sim 9.4$ years after the study entry and these were used to assess the stability of the dietary pattern over time.

\section{Statistical analysis}

In discovery analysis, we assessed the association between dietary nutrients and repeated $\mathrm{FEV}_{1}$ measurements collected at multiple visits in the LSC $(n=1,829)$ using linear mixed effects (LME) model with a subject-specific random intercept. A total of 8,468 postbronchodilator $\mathrm{FEV}_{1}$ measures were obtained from 1,829 LSC members over a median follow-up period of 5.3 years (interquartile range [IQR]: 1.5-10 years). The average interval between visits was 1.45 years with an IQR of 1.32-1.61 years. Covariates included baseline variables (eg, age, sex, ethnicity, smoking history [smoking status and pack-years], body mass index, educational level, and height), total calorie intake, and time since enrollment (TSE) at each PFT test. This analysis tested whether higher intake of protective or harmful nutrients was associated with on average better or worse $\mathrm{FEV}_{1}$ across multiple visits. Nutrients associated with repeated spirometry measurements with false discovery rate (FDR) $<0.05$ in the LSC were further assessed in the replication cohort (VSC, $n=508$ ). Because only spirometry data at study entry were available from the VSC, multivariate linear regression was used to assess the association between nutrients and $\mathrm{FEV}_{1}$. Nutrients associated with $\mathrm{FEV}_{1}$ with FDR $<0.05$ in the VSC were deemed 
as being replicated. Second, the effect of nutrients on $\mathrm{FEV}_{1}$ decline was assessed in LSC members $(n=1,499)$ with at least one follow-up visit and by including an interaction term between nutrient and TSE at each spirometry test in the LME model. In addition to the variables listed earlier, baseline $\mathrm{FEV}_{1}$ was further included as an independent variable for adjustment. Third, the ethnic disparity in nutrient intakes was assessed using multivariate linear regressions with natural log transformed nutrients as the outcome which had improved normality of the residual and satisfied the homoscedasticity assumption..$^{22}$ Covariates for adjustment included age, sex, smoking history (smoking status and pack-years), and total calorie intake. Finally, ethnic difference in magnitude of association between nutrients and $\mathrm{FEV}_{1}$ decline was assessed in the LSC by including a three-way interaction term among dietary intake, ethnicity, and TSE in the LME model. All statistical analyses were conducted in SAS 9.4.

\section{Results}

\section{Characteristics of the study subjects}

A total of 327 Hispanics and 1,502 NHWs from LSC and 164 Hispanics and 344 NHWs from VSC who had complete data for dietary intake and spirometry data were studied (Table 1). VSC members were older and predominantly male and had more former smokers and Hispanics compared to the LSC members. In addition, VSC enrolled light smokers ( $<10$ pack-years) who make up $16.7 \%$ of the cohort. The completeness of the FFQ and spirometry data at baseline was comparable between the two cohorts.

\section{Stability of dietary intake pattern}

A moderate to high correlation was identified for dietary nutrient intake between baseline and follow-up visits that were 9.4 years apart with a median spearman correlation coefficient $>0.60$. The median percentage of changes in nutrient levels in the second FFQ relative to the baseline one is $12.2 \%$ with an IQR of $6.7 \%-22.4 \%$. These findings support a relatively stable dietary pattern over a decade for the studied population.

\section{Nutrients affecting FEV,}

Thirty-three nutrient measurements were discovered to be associated with $\mathrm{FEV}_{1}$ with FDR $<0.05$ (not shown) and were further tested in the VSC. Fifteen nutrient measurements that assessed the dietary intakes of one mineral (magnesium), four vitamins (folate, niacin, A, and D), four long-chain unsaturated fatty acids (eicosenoic fatty acid [20:1n9], eicosapentaenoic acid [EPA, 20:5n3], docosapentaenoic acid
Table I Characteristics of LSC and VSC members

\begin{tabular}{|c|c|c|}
\hline Variable & LSC & VSC \\
\hline $\mathrm{n}$ & 1,829 & 508 \\
\hline $\begin{array}{l}\text { Age (years, } \\
\text { mean } \pm S D \text { ) }\end{array}$ & $57.2 \pm 9.4$ & $62.1 \pm 8.5$ \\
\hline Sex (male, \%) & 22.4 & 96.7 \\
\hline Hispanics (\%) & 17.9 & 32.3 \\
\hline $\begin{array}{l}\text { Current } \\
\text { smokers (\%) }\end{array}$ & 55.7 & 37.0 \\
\hline $\begin{array}{l}\text { Packyears (Pys, } \\
\text { median [QI-Q3]) }\end{array}$ & $35.0(26.0-49.0)$ & $32.5(15.0-58.0)$ \\
\hline$<10(\%)$ & 0 & 16.7 \\
\hline $10-29(\%)$ & 33.4 & 28.8 \\
\hline $29-43(\%)$ & 33.4 & 17.0 \\
\hline$\geq 43$ (\%) & 33.2 & 37.4 \\
\hline $\begin{array}{l}\text { Number of } \\
\text { unanswered food } \\
\text { items }\end{array}$ & $0(0-2)$ & $0(0-1)$ \\
\hline $\begin{array}{l}\text { Total calorie } \\
\text { intake (kcal) }\end{array}$ & I,724.7 (I,343.7-2, I77.4) & I,903.4 (I,405.3-2,493.5) \\
\hline $\begin{array}{l}\text { Number of } \\
\text { spirometry } \\
\text { (median [QI-Q3]) }\end{array}$ & $4(2-7)$ & $\mathrm{I}^{\mathrm{a}}$ \\
\hline Spirometry at basel & line & \\
\hline $\begin{array}{l}\mathrm{FEV},(\mathrm{L} / \mathrm{s}, \\
\text { mean } \pm \mathrm{SD})\end{array}$ & $2.5 \pm 0.7$ & $2.6 \pm 0.6$ \\
\hline $\begin{array}{l}\mathrm{FVC}(\mathrm{L}, \\
\text { mean } \pm \mathrm{SD})\end{array}$ & $3.4 \pm 0.9$ & $3.5 \pm 0.7$ \\
\hline $\begin{array}{l}\mathrm{FEV}_{1} / \mathrm{FVC} \\
(\%, \text { mean } \pm \mathrm{SD})\end{array}$ & $72.8 \pm 10.7$ & $72.5 \pm 11.6$ \\
\hline
\end{tabular}

Note: anly spirometry data at study entry in the VSC was available for this study. Abbreviations: LSC, Lovelace Smokers cohort; VSC, Veteran Smokers cohort; $\mathrm{SD}$, standard deviation; Q, quartile; FEV , forced expiratory volume in I s; FVC, forced vital capacity.

[DPA; 22:5n3], docosahexaenoic acid [DHA; 22:6n3]), and the Association of Official Agricultural Chemists (AOAC) fiber were significantly associated with greater $\mathrm{FEV}_{1}$, while trans-oleic fatty acid measurement was associated with worse $\mathrm{FEV}_{1}$ in the VSC (FDR <0.05; Table 2). A combinational effect of the protective nutrients (magnesium, folate, niacin, vitamins $A$ and $D$, long chain N3 fatty acids $[\mathrm{EPA}+\mathrm{DPA}+\mathrm{DHA}]$, and AOAC fiber) was assessed by creating a score that sums the standardized intakes of these nutrients. The differences of $\mathrm{FEV}_{1}$ between cohort members with high (upper quartile) versus low (lower quartile) scores were $183.4 \pm 42.2 \mathrm{~mL} / \mathrm{s}(P<0.0001)$ in the LSC and $307.4 \pm 93.4 \mathrm{~mL} / \mathrm{s}(P=0.0011)$ in the VSC.

\section{Nutrients affecting FEV, decline}

The effect of dietary nutrients on $\mathrm{FEV}_{1}$ decline was assessed by including an interaction term between each individual nutrient and TSE in the LME model in 1,499 LSC members with $\geq 2$ spirometry tests. This analysis was conducted for 
Table 2 Nutrients associated with FEV $(\mathrm{mL} / \mathrm{s})$ in the LSC and VSC $^{a}$

\begin{tabular}{|c|c|c|c|c|}
\hline \multirow[t]{2}{*}{ Nutrient (U/day) ${ }^{b}$} & \multicolumn{2}{|c|}{$\operatorname{LSC}(n=I, 829)$} & \multicolumn{2}{|l|}{$\operatorname{VSC}(n=508)$} \\
\hline & $\begin{array}{l}\text { Estimate } \\
\text { (SE) }\end{array}$ & FDR & $\begin{array}{l}\text { Estimate } \\
\text { (SE) }\end{array}$ & FDR \\
\hline \multicolumn{5}{|l|}{ Minerals } \\
\hline Magnesium (I74.7 mg) & $82.2(20.0)$ & 0.0027 & $202.6(55.8)$ & 0.011 \\
\hline Magnesium (144.7 mg) & I07.I (24.2) & 0.0014 & I56.8 (58.1) & 0.031 \\
\hline \multicolumn{5}{|l|}{ Vitamins } \\
\hline $\begin{array}{l}\text { Total folate intake } \\
(478.6 \mu \mathrm{g})\end{array}$ & $61.4(17.7)$ & 0.010 & I36.I (42.5) & 0.021 \\
\hline Folic acid $(4 \mid \mathrm{I} .0 \mu \mathrm{g})$ & $43.5(16.4)$ & 0.039 & II $2.2(38.7)$ & 0.026 \\
\hline $\begin{array}{l}\text { Folate equivalents } \\
(860.5 \mu \mathrm{g})\end{array}$ & $52.6(16.8)$ & 0.022 & I28.I (40.6) & 0.021 \\
\hline Niacin (24.8 mg) & $24.0(7.8)$ & 0.022 & $93.1(33.2)$ & 0.027 \\
\hline Vitamin A $(9,160.2 \mathrm{IU})$ & $37.6(13.5)$ & 0.030 & $66.7(29.3)$ & 0.050 \\
\hline Vitamin D (468.9 IU) & $40.4(15.2)$ & 0.039 & $119.6(4 \mid .8)$ & 0.026 \\
\hline \multicolumn{5}{|l|}{ Fatty acids } \\
\hline $\begin{array}{l}\text { Eicosenoic fatty acid } \\
\text { (135 mg) }\end{array}$ & $34.4(13.5)$ & 0.049 & $70.6(29.7)$ & 0.045 \\
\hline EPA (I00 mg) & $17.9(6.1)$ & 0.025 & $34.0(14.5)$ & 0.045 \\
\hline DPA (20 mg) & $29.9(10.2)$ & 0.025 & $68.0(22.3)$ & 0.021 \\
\hline DHA (I50 mg) & $27.6(10.3)$ & 0.039 & $61.4(23.7)$ & 0.033 \\
\hline $\begin{array}{l}\text { EPA + DPA + DHA } \\
(310 \mathrm{mg})\end{array}$ & $28.0(9.7)$ & 0.025 & $57.0(22.3)$ & 0.033 \\
\hline $\mathrm{EPA}+\mathrm{DHA}(290 \mathrm{mg})$ & $27.6(9.6)$ & 0.025 & $55.8(22.2)$ & 0.034 \\
\hline trans-oleic ( $1.2 \mathrm{~g})$ & $-75.9(29.8)$ & 0.049 & $-112.3(42.0)$ & 0.031 \\
\hline AOAC fiber $(10.5 \mathrm{~g})$ & $80.9(20.3)$ & 0.0032 & $97.8(41.8)$ & 0.045 \\
\hline
\end{tabular}

Notes: EPA, eicosapentaenoic fatty acid 20:5n3; DPA, docosapentaenoic fatty acid 22:5n3; DHA, docosahexaenoic fatty acid 22:6n3; eicosenoic fatty acid 20: In9. alQR is used for calculating the estimate and SE. Association analysis in the LSC was conducted based on longitudinal spirometry data using LME model with adjustment for important covariates. Association analysis in the VSC was conducted based on baseline spirometry data using linear regression with adjustment for important covariates. ${ }^{b}$ Assessment of total folate intake and folate equivalents includes all sources (ie, natural food, supplements, and fortified foods). Folic acid is from supplements and fortified foods. A total of $38 \%$ study subjects have missing data for trans-oleic fatty acid. 'Estimate of intake without counting supplement.

Abbreviations: $\mathrm{FEV}_{1}$, forced expiratory volume in I s; LSC, Lovelace Smokers cohort; VSC, Veteran Smokers cohort; SE, standard error; FDR, false discovery rate; AOAC, the Association of Official Agricultural Chemists; IQR, interquartile range; LME, linear mixed effects.

nutrients significantly associated with $\mathrm{FEV}_{1}$ (Table 2) to minimize the number of comparisons and it found eicosenoic fatty acid and DPA significantly associated with slower $\mathrm{FEV}_{1}$ decline $(P<0.05$, Table 3$)$.

\section{Antagonism of nutrients against cigarette smoking induced FEV, decline}

Cohort members were classified into continuous current smokers $(n=507)$, continuous abstainers $(n=620)$, quitters (current smokers at baseline who quit during follow-up visits and maintained the abstinence status afterward, $n=215$ ), and relapsers $(n=157)$. Compared to continuous current smokers $(-27.1 \pm 1.1 \mathrm{~mL} / \mathrm{s}$ per year), continuous abstainers $(-18.9 \mathrm{~mL} / \mathrm{s}$ per year, $P<0.0001)$, quitters $(-22 \mathrm{~mL} / \mathrm{s}$ per year, $P=0.0069)$, and relapsers $(-19.2 \mathrm{~mL} / \mathrm{s}$ per year, $P=0.0003)$
Table 3 The association between long chain unsaturated fatty acid and FEV, decline $(\mathrm{mL} / \mathrm{s})$ in the LSC $(\mathrm{n}=1,499)^{\mathrm{a}}$

\begin{tabular}{|c|c|c|c|c|c|}
\hline \multirow{2}{*}{$\begin{array}{l}\text { Nutrient } \\
\text { (U/day) }\end{array}$} & \multirow{2}{*}{$\begin{array}{l}\text { Time } \\
\text { Estimate } \\
(\mathrm{SE})^{\mathrm{b}}\end{array}$} & \multicolumn{2}{|l|}{ Nutrients } & \multicolumn{2}{|c|}{ Time $\times$ nutrients } \\
\hline & & $\begin{array}{l}\text { Estimate } \\
\text { (SE) }\end{array}$ & $P$-value & $\begin{array}{l}\text { Estimate } \\
\text { (SE) }\end{array}$ & $P$-value \\
\hline $\begin{array}{l}\text { Eicosenoic fatty } \\
\text { acid (I } 35 \mathrm{mg} \text { ) }\end{array}$ & $-24.0(1.1)$ & $3.2(5.3)$ & 0.55 & $1.6(0.6)$ & 0.0064 \\
\hline EPA (100 mg) & $-22.0(0.7)$ & $2.4(2.5)$ & 0.33 & $0.3(0.3)$ & 0.28 \\
\hline DPA (20 mg) & $-23.1(0.9)$ & $3.5(4.1)$ & 0.40 & I.2(0.5) & 0.022 \\
\hline DHA (I50 mg) & $-22.6(0.9)$ & $2.7(4.2)$ & 0.52 & $0.9(0.5)$ & 0.073 \\
\hline $\begin{array}{l}\text { EPA + DPA + } \\
\text { DHA (310 mg) }\end{array}$ & $-22.3(0.8)$ & $3.2(3.9)$ & 0.41 & $0.7(0.5)$ & 0.14 \\
\hline $\begin{array}{l}E P A+D H A \\
(290 \mathrm{mg})\end{array}$ & $-22.3(0.8)$ & $3.2(3.9)$ & 0.40 & $0.7(0.5)$ & 0.15 \\
\hline
\end{tabular}

Notes: EPA, eicosapentaenoic fatty acid 20:5n3; DPA, docosapentaenoic fatty acid 22:5n3; DHA, docosahexaenoic fatty acid 22:6n3; eicosenoic fatty acid 20: In9. ${ }^{2} \mathrm{QR}$ is used for calculating the estimate and SE. Association analysis in the LSC was conducted based on longitudinal spirometry data using linear mixed effects model with adjustment for important covariates. ${ }^{b} P<0.0001$.

Abbreviations: FEV , forced expiratory volume in I s; LSC, Lovelace Smokers cohort; SE, standard error; IQR, interquartile range.

had a significantly reduced $\mathrm{FEV}_{1}$ decline. Eicosenoic fatty acid and DPA were converted into binary variables based on the median levels seen in the LSC to facilitate the assessment of three-way interactions among nutrients, smoking behavior change, and TSE using the LME model (Table 4). Continuous abstainers, quitters, and relapsers were combined into one group as noncontinuous current smokers because their $\mathrm{FEV}_{1}$ decline rates were similar and the effect of nutrients on $\mathrm{FEV}_{1}$ decline showed no difference among these three subgroups (all $P>0.65$ ). Significant three-way interaction was identified among DPA intake status ( $>20$ versus $\leq 20 \mathrm{mg} /$ day), continuous current smoking, and TSE $(6.4 \pm 3.0, P=0.031$,

Table 4 Antagonism of nutrients against cigarette smoking induced FEV, decline $(\mathrm{mL} / \mathrm{s})$ in the LSC $(\mathrm{n}=\mathrm{I}, 499)^{\mathrm{a}}$

\begin{tabular}{|c|c|c|c|c|c|}
\hline \multirow[t]{2}{*}{$\begin{array}{l}\text { Nutrient } \\
\text { (U/day) }\end{array}$} & \multirow{2}{*}{$\begin{array}{l}\text { Time } \\
\text { Estimate } \\
(\mathrm{SE})^{\mathrm{b}}\end{array}$} & \multicolumn{2}{|c|}{$\begin{array}{l}\text { Continuous } \\
\text { smoking }\end{array}$} & \multicolumn{2}{|c|}{$\begin{array}{l}\text { Time } \times \text { continuous } \\
\text { smoking }\end{array}$} \\
\hline & & $\begin{array}{l}\text { Estimate } \\
\text { (SE) }\end{array}$ & $P$-va & $\begin{array}{l}\text { Estimate } \\
\text { (SE) }\end{array}$ & $P$-value \\
\hline All & $-19.6(0.7)$ & $8.5(12.5)$ & 0.5 & $-7.5(\mathrm{I} .3)$ & 001 \\
\hline \multicolumn{6}{|l|}{$\mathrm{DPA}^{\mathrm{c}}$} \\
\hline$>20 \mathrm{mg}$ & -19.7( & -5.2 & 0.82 & $-2.8(2.5)$ & 0.26 \\
\hline$\leq 20 \mathrm{mg}$ & $-19.5(0.9)$ & $16.0(14.9)$ & 0.28 & $-9.2(1.6)$ & $<0.0001$ \\
\hline \multicolumn{6}{|c|}{ Eicosenoic fatty acidd } \\
\hline$>135 \mathrm{mg}$ & $-18.7(1.0)$ & $24.6(19$ & 0.20 & $-7.5(2.1)$ & 0.0004 \\
\hline$\leq 135 \mathrm{mg}$ & $-20.3(0.9)$ & $-0.3(16.3)$ & 0.99 & $-7.4(\mathrm{I} .7)$ & $<0.000 \mathrm{I}$ \\
\hline
\end{tabular}

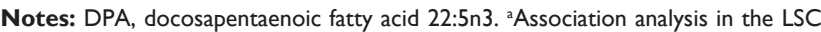
was conducted based on longitudinal spirometry data using linear mixed effects model with adjustment for important covariates. ${ }^{b} P<0.000$ I. ${ }^{C} P$-value for three-way interaction among DPA, continuous smoking, and TSE $=0.03 \mathrm{I}$. ${ }^{\mathrm{d} P} \mathrm{P}$-value for threeway interaction among eicosenoic fatty acid, continuous smoking, and TSE $=0.99$.

Abbreviations: FEV , forced expiratory volume in I s; LSC, Lovelace Smokers cohort; SE, standard error; TSE, time since enrollment. 
Table 5 Ethnic disparity in dietary intakes of eicosenoic fatty acid and DPA in the LSC and VSCa

\begin{tabular}{|c|c|c|c|c|}
\hline Cohort & Nutrient (U/day) & NHWs & Hispanics & $P$-value \\
\hline \multirow[t]{3}{*}{ LSC } & & $\mathrm{n}=1,502$ & $n=327$ & \\
\hline & Eicosenoic fatty acid (mg) & $173.3(\mid 20.1-250.1)$ & $169.3(120.1-260.1)$ & 0.41 \\
\hline & $\mathrm{DPA}(\mathrm{mg})$ & $14.3(10.1-30.1)$ & $8.0(10.1-30.1)$ & $1.6 \times 10^{-5}$ \\
\hline \multirow[t]{3}{*}{ VSC } & & $\mathrm{n}=344$ & $n=164$ & \\
\hline & Eicosenoic fatty acid (mg) & $212.9(140.1-320.1)$ & $200.7(130.1-305.0)$ & 0.0016 \\
\hline & DPA (mg) & $12.1(10.1-30.1)$ & $8.7(10.1-20.1)$ & 0.0092 \\
\hline
\end{tabular}

Notes: DPA, docosapentaenoic fatty acid 22:5n3. ${ }^{2}$ Age, sex, smoking history (smoking status and pack-years), BMI, educational level, and total calorie intake were adjusted in multivariate linear regression with natural log transformed nutrients as the outcome. Data are shown as geometric means with lower and upper quartiles. Total calorie intake was I,890.2 \pm 7 I6.I versus I,796.4 \pm 6 I9.I for Hispanics and NHWs (Wilcoxon test, $P=0.067$ ) in the LSC and 2, I84.3 \pm I,247.6 versus 2,00I.3 \pm 793.4 for Hispanics and NHWs (Wilcoxon test, $P=0.65$ ) in the VSC.

Abbreviations: LSC, Lovelace Smokers cohort; VSC, Veteran Smokers cohort; NHWs, non-Hispanic whites; BMI, body mass index.

Table 4). Stratified analysis by DPA intake status identified that the adverse effect of continuous current smoking on $\mathrm{FEV}_{1}$ decline was completely negated in LSC members with higher DPA intake status ( $P=0.26$, Table 4$)$. The association between continuous smoking and $\mathrm{FEV}_{1}$ decline was independent of intake status of eicosenoic fatty acid.

\section{Effect of dietary intakes of eicosenoic fatty acid and DPA on the ethnic disparity of $F E V$, decline}

Our previous study identified that Hispanics smokers had significantly lower COPD prevalence than NHWs in the LSC and this ethnic disparity may be due to the slower $\mathrm{FEV}_{1}$ decline in Hispanics. ${ }^{1}$ We hypothesized that ethnic disparity in $\mathrm{FEV}_{1}$ decline may be partially explained by the dietary intakes of eicosenoic fatty acid and DPA. We first assessed whether Hispanic smokers consume more protective nutrients. Surprisingly, although the total calorie intake was quite comparable between Hispanics and NHWs, Hispanics consume 44 and $28 \%$ less DPA than NHWs in LSC and VSC, respectively $(P<0.01$, Table 5$)$. The difference of consumption of eicosenoic fatty acid between Hispanics and NHWs is very minimal in both cohorts (Table 5). Second, we assessed whether protective nutrients have a stronger favorable association with $\mathrm{FEV}_{1}$ decline in Hispanics compared to NHWs. A significant three-way interaction among DPA intake status, ethnicity, and TSE was identified (9.3 \pm 3.6 , $P=0.0095$, Table 6), while the three-way interaction among eicosenoic fatty acid intake status, ethnicity, and TSE was of borderline significance (5.7 $\pm 3.3, P=0.082$, Table 6). Most importantly, the associations between greater intake status of DPA and eicosenoic fatty acid and reduced $\mathrm{FEV}_{1}$ decline were 8.8- and 5.7-fold greater in Hispanics compared to NHWs for DPA and eicosenoic fatty acid, respectively (Table 6). Thus, the ethnic disparity in $\mathrm{FEV}_{1}$ decline may be due to the greater protective effects on $\mathrm{FEV}_{1}$ decline seen in Hispanics versus NHWs.

\section{Discussion}

Our comprehensive nutritional study through assessing dietary intake of 139 nutrients in 2,367 smokers from NM identified magnesium, folate, niacin, vitamins $\mathrm{A}$ and $\mathrm{D}$, and long chain unsaturated fatty acids (eicosenoic fatty acid and n-3 PUFAs), and dietary fiber as associated with on average better FEV 1 in chronic smokers. In addition, the effect of these protective nutrients on lung function showed an obstructive

Table 6 Magnitude of association between dietary nutrients and FEV, decline $(\mathrm{mL} / \mathrm{s})$ in Hispanics and NHWs in the LSC ( $\mathrm{n}=1,499)^{\mathrm{a}}$

\begin{tabular}{|c|c|c|c|c|c|c|}
\hline \multirow[t]{2}{*}{ Nutrient ${ }^{b}$} & \multirow[t]{2}{*}{ Ethnicity } & \multirow{2}{*}{$\begin{array}{l}\text { Time } \\
\text { Estimate } \\
(\mathrm{SE})^{\mathrm{c}}\end{array}$} & \multicolumn{2}{|l|}{ Nutrient } & \multicolumn{2}{|c|}{ Time $\times$ nutrient } \\
\hline & & & $\begin{array}{l}\text { Estimate } \\
(\mathrm{SE})\end{array}$ & $P$-value & $\begin{array}{l}\text { Estimate } \\
(\mathrm{SE})\end{array}$ & $P$-value \\
\hline \multirow[t]{2}{*}{$\mathrm{DPA}^{\mathrm{d}}$} & Hispanics & $-22.3(1.8)$ & $4.2(26.4)$ & 0.87 & $10.5(3.4)$ & 0.0020 \\
\hline & NHWs & $-22.5(0.8)$ & $17.2(10.8)$ & 0.11 & I.2 (I.3) & 0.35 \\
\hline \multirow[t]{2}{*}{ Eicosenoic fatty acide } & Hispanics & $-22.0(1.9)$ & $-29.1(26.5)$ & 0.27 & $6.8(3.1)$ & 0.028 \\
\hline & NHWs & $-22.5(0.8)$ & I7.6 (II.6) & 0.13 & I.2(I.3) & 0.34 \\
\hline
\end{tabular}

Notes: DPA, docosapentaenoic fatty acid 22:5n3. ${ }^{a}$ Association analysis in the LSC was conducted based on longitudinal spirometry data using linear mixed effects model with adjustment for important covariates. 'Eicosenoic fatty acid and DPA were converted into binary variables based on the median levels seen in the LSC (Table 4). ${ }^{c} P<0.000$ I. ${ }^{d} P$-value for three-way interaction among DPA, ethnicity, and TSE $=0.0095$. ${ }^{e} P$-value for three-way interaction among eicosenoic fatty acid, ethnicity, and TSE $=0.082$.

Abbreviations: FEV , forced expiratory volume in I s; NHWs, non-Hispanic whites; LSC, Lovelace Smokers cohort; SE, standard error; TSE, time since enrollment. 
pattern as their associations with $\mathrm{FEV}_{1} / \mathrm{FVC}$ were significant as well (Table S1). ${ }^{24}$ The differences of $\mathrm{FEV}_{1}$ between cohort members consuming high (upper quartile) versus low (lower quartile) levels of individual protective nutrients ranged from 17.9 to $107.1 \mathrm{~mL} / \mathrm{s}$ with a combinational effect of $183.4 \mathrm{~mL} / \mathrm{s}$ in the LSC. The protective effects became even greater in an older population comprising of predominantly males (VSC). The factors contributing to the observed greater effects in the VSC compared to the LSC are largely unknown and may include sample size, sex difference, age, smoking status, etc. These differences are of substantial public health impact because normal FEV 1 loss per year in the LSC is $\sim 22 \mathrm{~mL} / \mathrm{s}$ per year and the $\mathrm{FEV}_{1}$ difference between current and former smokers is $82 \mathrm{~mL} / \mathrm{s}$. Our study is also the first to identify two long chain unsaturated fatty acids (ie, eicosenoic fatty acid and DPA) associated with on average better $\mathrm{FEV}_{1}$ through reducing age-related $\mathrm{FEV}_{1}$ decline in moderate and heavy smokers. In addition, the effect of these two nutrients on lung function decline showed an obstructive pattern as their associations with $\mathrm{FEV}_{1} / \mathrm{FVC}$ were significant as well (Table S2). Our findings together with others ${ }^{7-9,11,12}$ suggest that protective dietary nutrients may improve lung function through two hypothetical patterns: symptom-improving pattern for magnesium, folate, niacin, vitamins A and D, EPA, DHA, and dietary fiber (Figure 1A) and slowing the age-related lung function decline pattern for eicosenoic fatty acid and DPA (Figure 1B).

Among n-3 PUFAs, daily intake of n-3 DPA is $<20 \%$ of EPA and DHA in the LSC. Similar dietary intake pattern was also observed in 13,000 Dutch adults. ${ }^{25}$ However, the protective effect of DPA for average $\mathrm{FEV}_{1}$ is the most potent, as per $100 \mathrm{mg}$ increase in daily intake $\mathrm{FEV}_{1}$ increases by $149.5 \mathrm{~mL} / \mathrm{s}$ for DPA, $17.9 \mathrm{~mL} / \mathrm{s}$ for EPA, and $18.4 \mathrm{~mL} / \mathrm{s}$ for DHA. Furthermore, DPA is the only one that has a statistically significant association with a slower $\mathrm{FEV}_{1}$ decline $(P=0.022)$.
Among the three n-3 PUFAs, a more potent effect associated with DPA intake has also been seen in the Edinburgh Artery Study in which DPA was the only n-3 PUFA that reduced the likelihood of developing atherosclerosis. ${ }^{26}$ In addition, in a multiethnic cohort of 2,837 American adults, dietary intake of DPA was the most potent n-3 PUFA associated with reduced risk for incident cardiovascular disease and coronary heart disease, and plasma phospholipid DPA had the strongest inverse correlation with systemic inflammation markers (ie, IL-6 and CRP). ${ }^{27}$ The mechanism underlying the protective effect of DPA on lung function may be related to its anti-inflammatory, antiproteolytic, and antioxidative ability. EPA supplementation in macrophages exerts antiinflammatory effects indirectly through its elongation to DPA that inhibited the proinflammatory mediators derived from cyclooxygenase metabolism. ${ }^{28}$ In a rat model of pulmonary hypertension, oral administration of DPA for 3 weeks decreased NF- $\kappa$ B and p38 MAPK activation, leading to a reduction in MMP-2, MMP-9, and VEGF expression levels in lung tissue homogenates. ${ }^{29}$ The degradation of the extracellular matrix by specialized proteolytic enzymes such as matrix metalloproteinases has been shown to play a key pathogenic role in the development of important COPD phenotype emphysema. ${ }^{30}$ In aged rats, DPA-supplemented diet restored the neuronal function through blocking oxidative changes as quantified by measuring $8-\mathrm{OHdG}$ in the hippocampus and its subsequent activation of sphingomyelinase and caspase 3 activity. ${ }^{31} 8-\mathrm{OHdG}$ is an indicator of reactive oxygen speciesinduced oxidative DNA damage, and compared to healthy smokers, smokers with COPD had significantly elevated levels of 8-OHdG in peripheral blood DNA, a biomarker highly correlated with $8-\mathrm{OHdG}$ in the lung and reduced $\mathrm{FEV}_{1} \cdot{ }^{32}$ The antioxidant role of DPA was further supported by the finding that a significant interaction between DPA intake
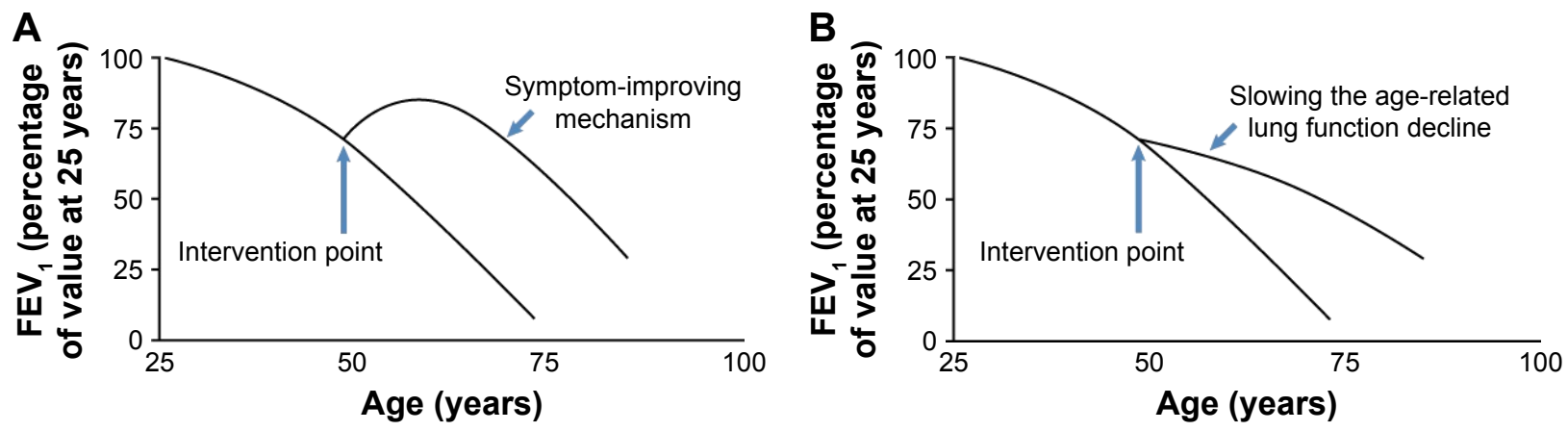

Figure I Two hypothetical models for the effect of dietary intervention on lung function.

Notes: (A) The nutrient supplementation at optimal physiological level may improve lung function that in turn offsets the age-related decline over time. In this pattern, the onset of the intervention improves the lung function without affecting the decline slope. (B) The intervention could directly slow down the age-related lung function decline as reflected by a less steep slope.

Abbreviation: $\mathrm{FEV}_{1}$, forced expiratory volume in I s. 
and continuous smoking on $\mathrm{FEV}_{1}$ decline was identified and the greater intake of DPA $<20 \mathrm{mg} /$ day completely negated the effect of continuous smoking on $\mathrm{FEV}_{1}$ decline.

Eicosenoic fatty acid is a monounsaturated fatty acid with fatty fish as the main food source. Its average intake in human diet is $207.0 \mathrm{mg}$ /day. Using the lipopolysaccharide (LPS)-induced RAW 264.7 macrophages model of inflammation, preincubation of macrophages with eicosenoic fatty acid significantly reduced LPS-induced inducible nitric oxide synthase (iNOS) levels. ${ }^{33}$ iNOS plays an important role in determining nitrosative stress in the lung, as it produces large amounts of nitric oxide (NO) in response to many endogenous (such as chemokines and cytokines) and exogenous stimuli (such as bacterial toxins, virus infection, allergens, environmental pollutants [ozone, oxidative stress, and silica], hypoxia, and tumors). ${ }^{34} \mathrm{NO}$ reacts with superoxides to form the highly reactive peroxynitrites that have been shown to further produce airway inflammation and cause airway remodeling. ${ }^{35-37}$ However, cigarette smoking has been shown to reduce the proinflammatory factors induced iNOS expression in lung epithelial cells and exhaled NO levels among smokers. ${ }^{38,39}$ Interestingly, we did not find any interaction between eicosenoic fatty acid and continuous smoking on $\mathrm{FEV}_{1}$ decline in our study. Taken together, our results suggest that greater intake of eicosenoic fatty acid may reduce the $\mathrm{FEV}_{1}$ decline through alleviating iNOS-mediated nitrosative stress in a cigarette smoke-independent manner.

In this study, we provided the first evidence that instead of greater intakes of these two protective nutrients, it was the much larger protective effect of eicosenoic fatty acid and DPA on $\mathrm{FEV}_{1}$ decline seen in Hispanics that may partially explain why Hispanics had slower FEV 1 decline. The underlying mechanism for dietary intake of DPAmediated ethnic disparity in $\mathrm{FEV}_{1}$ decline may be related to the ethnic disparity in the metabolism of DPA. Only weak associations were identified between fish consumption and plasma phospholipid DPA, suggesting that endogenous metabolism influences circulating DPA concentrations, for example, by chain elongation and desaturation of EPA. ${ }^{27,40,41}$ In addition, although average dietary intake of DPA in Hispanics was $\sim 75 \%$ of that seen in NHWs, plasma phospholipid DPA level was very similar between the two ethnic groups. ${ }^{27}$ Sequence variants of enzymes involved in this metabolic conversion are associated with DPA levels with several clearly showing ethnic differences in minor allele frequency between HapMap populations of European and Hispanic ancestry. ${ }^{42}$ For example, C allele of rs3734398 in elongase gene ELOVL2 was associated with higher levels of
EPA and DPA and lower levels of DHA, suggesting that C allele decreases the conversion of EPA and DPA to DHA. Frequency of the $\mathrm{C}$ allele of rs 3734398 was 0.44 and 0.71 in HapMap populations of European and Hispanic ancestry, respectively. Thus, greater $\mathrm{C}$ allele frequency in Hispanics may potentially contribute to greater circulating DPA concentrations, which in turn exaggerate the health effects of DPA. Thus, the larger protective effect of dietary intake of DPA on $\mathrm{FEV}_{1}$ decline seen in Hispanics compared to NHWs may be due to greater metabolism favoring DPA accumulation and its subsequent lung effects in Hispanics.

This study has several strengths. First, this is one of the first studies taking an unbiased approach to identify nutrients associated with longitudinal spirometry measurements in moderate and heavy smokers. Second, a rigorous analytical plan that incorporated a discovery and replication approach and FDR correction was taken to minimize the chance of false-positive findings. Finally, NM populations provided a unique opportunity to reliably assess the ethnic disparity in lung function. NM Hispanics are distinct from Hispanic or Latino populations living in other states because they mainly include descendants of Spanish colonists who have settled the area of NM and Southern Colorado since the 1600s. Thus, our findings of ethnic disparity are not likely to be affected by immigration-related factors such as acculturation status, healthy migrant effect, and salmon bias. However, this may be an indicator that the study results may not be generalized to the overall Hispanic populations across the United States.

This study has two limitations. First, our studies and others have shown that the dietary pattern in adults is reasonably stable over several years. ${ }^{22}$ However, because the FFQ was not implemented in follow-up visits, we are not able to identify nutrients whose changes over time will affect lung function decline. The implementation of the FFQ in follow-up visits in the future would make this test possible. Second, the average lung function in the LSC members is relatively healthy with only $25 \%$ of subjects with COPD disease defined by Global Initiative for Chronic Obstructive Lung Disease criteria, most of whom have mild-to-moderate COPD. Thus, whether our findings could be generalized to COPD patients is uncertain.

\section{Conclusion}

Through an unbias nutrientomics study, we identified magnesium, folate, niacin, vitamins A and D, long chain unsaturated fatty acids (eicosenoic fatty acid and n-3 PUFA), and dietary fiber associated with on average better $\mathrm{FEV}_{1}$ in chronic smokers. In addition, dietary intakes of eicosenoic fatty acid and DPA were associated with reduced $\mathrm{FEV}_{1}$ decline. These findings 
could lay foundation for the design of an individualized nutritional intervention targeting "optimal physiological levels" in human to improve lung function in ever smokers. Furthermore, slower $\mathrm{FEV}_{1}$ decline in Hispanics versus NHWs may be partially due to greater protective effect of eicosenoic fatty acid and DPA on age-related $\mathrm{FEV}_{1}$ decline.

\section{Acknowledgments}

We thank Ms Laura Sampson, MS RD, at Harvard School of Public Health for assisting result interpretation. We thank Ms Xiequn Zhang, MS, at Lovelace Respiratory Research Institute for processing dietary data. We thank Ms Elise Calvillo for scientific editing of the figures. We thank the staff from Lovelace Scientific Resources for recruiting and enrolling study subjects and collecting lung function data. We thank the NM residents who participated in this study. This research was supported by NCI grant R01 CA097356, the State of New Mexico, as a direct appropriation from the Tobacco Settlement Fund and NIH/NCI P30 CA118100.

\section{Disclosure}

The authors report no financial and nonfinancial competing interests in this work.

\section{References}

1. Bruse S, Sood A, Petersen H, et al. New Mexican Hispanic smokers have lower odds of chronic obstructive pulmonary disease and less decline in lung function than non-Hispanic whites. Am J Respir Crit Care Med. 2011;184(11):1254-1260.

2. Sood A, Petersen H, Blanchette CM, et al. Wood smoke exposure and gene promoter methylation are associated with increased risk for COPD in smokers. Am J Respir Crit Care Med. 2010;182(9):1098-1104.

3. Lange P, Celli B, Agusti A, et al. Lung-function trajectories leading to chronic obstructive pulmonary disease. $N$ Engl J Med. 2015;373(2): 111-122.

4. Hanson C, Rutten EP, Wouters EF, Rennard S. Influence of diet and obesity on COPD development and outcomes. Int J Chron Obstruct Pulmon Dis. 2014;9:723-733.

5. Romieu I, Trenga C. Diet and obstructive lung diseases. Epidemiol Rev. 2001;23(2):268-287.

6. Fonseca Wald EL, van den Borst B, Gosker HR, Schols AM. Dietary fibre and fatty acids in chronic obstructive pulmonary disease risk and progression: a systematic review. Respirology. 2014;19(2):176-184.

7. Carey IM, Strachan DP, Cook DG. Effects of changes in fresh fruit consumption on ventilatory function in healthy British adults. $\mathrm{Am} J$ Respir Crit Care Med. 1998;158(3):728-733.

8. Guenegou A, Leynaert B, Pin I, Le Moel G, Zureik M, Neukirch F. Serum carotenoids, vitamins $\mathrm{A}$ and $\mathrm{E}$, and 8 year lung function decline in a general population. Thorax. 2006;61(4):320-326.

9. McKeever TM, Lewis SA, Cassano PA, et al. Patterns of dietary intake and relation to respiratory disease, forced expiratory volume in $1 \mathrm{~s}$, and decline in 5-y forced expiratory volume. Am J Clin Nutr. 2010;92(2): 408-415.

10. Bentley AR, Kritchevsky SB, Harris TB, et al; Health ABC Study. Dietary antioxidants and forced expiratory volume in $1 \mathrm{~s}$ decline: the Health, Aging and Body Composition study. Eur Respir J. 2012;39(4): 979-984.
11. Butland BK, Fehily AM, Elwood PC. Diet, lung function, and lung function decline in a cohort of 2512 middle aged men. Thorax. 2000; 55(2):102-108.

12. McKeever TM, Scrivener S, Broadfield E, Jones Z, Britton J, Lewis SA. Prospective study of diet and decline in lung function in a general population. Am J Respir Crit Care Med. 2002;165(9):1299-1303.

13. Shaheen SO, Jameson KA, Syddall HE, et al; Hertfordshire Cohort Study Group. The relationship of dietary patterns with adult lung function and COPD. Eur Respir J. 2010;36(2):277-284.

14. Varraso R, Fung TT, Barr RG, Hu FB, Willett W, Camargo CA Jr. Prospective study of dietary patterns and chronic obstructive pulmonary disease among US women. Am J Clin Nutr. 2007;86(2):488-495.

15. Varraso R, Fung TT, Hu FB, Willett W, Camargo CA. Prospective study of dietary patterns and chronic obstructive pulmonary disease among US men. Thorax. 2007;62(9):786-791.

16. Pew Hispanic Center [webpage on the Internet]. Demographic Profile of Hispanics in New Mexico, 2011; 2016. Available from: http://www. pewhispanic.org/states/state/nm/. Accessed Feburary 3, 2016.

17. Leng S, Liu Y, Thomas CL, et al. Native American ancestry affects the risk for gene methylation in the lungs of Hispanic smokers from New Mexico. Am J Respir Crit Care Med. 2013;188(9):1110-1116.

18. Chen W, Brehm JM, Boutaoui N, et al. Native American ancestry, lung function, and COPD in Costa Ricans. Chest. 2014;145(4):704-710.

19. Chen W, Brehm JM, Manichaikul A, et al. A genome-wide association study of chronic obstructive pulmonary disease in Hispanics. Ann Am Thorac Soc. 2015;12(3):340-348.

20. Leng S, Stidley CA, Willink R, et al. Double-strand break damage and associated DNA repair genes predispose smokers to gene methylation. Cancer Res. 2008;68(8):3049-3056.

21. Standardization of spirometry, 1994 update. American Thoracic Society. Am J Respir Crit Care Med. 1995;152(3):1107-1136.

22. Rimm EB, Giovannucci EL, Stampfer MJ, Colditz GA, Litin LB, Willett WC. Reproducibility and validity of an expanded selfadministered semiquantitative food frequency questionnaire among male health professionals. Am J Epidemiol. 1992;135(10):1114-1126. Discussion 1127-1136.

23. Pareo-Tubbeh SL, Romero LJ, Baumgartner RN, Garry PJ, Lindeman RD, Koehler KM. Comparison of energy and nutrient sources of elderly Hispanics and non-Hispanic whites in New Mexico. J Am Diet Assoc. 1999;99(5):572-582.

24. Occhipinti M, Larici AR, Bonomo L, Incalzi RA. Aging airways: between normal and disease. A multidimensional diagnostic approach by combining clinical, functional, and imaging data. Aging Dis. 2017; 8(4):471-485.

25. McKeever TM, Lewis SA, Cassano PA, et al. The relation between dietary intake of individual fatty acids, $\mathrm{FEV}_{1}$ and respiratory disease in Dutch adults. Thorax. 2008;63(3):208-214.

26. Leng GC, Horrobin DF, Fowkes FG, et al. Plasma essential fatty acids, cigarette smoking, and dietary antioxidants in peripheral arterial disease. A population-based case-control study. Arterioscler Thromb. 1994;14(3):471-478.

27. de Oliveira Otto MC, Wu JH, Baylin A, et al. Circulating and dietary omega- 3 and omega- 6 polyunsaturated fatty acids and incidence of CVD in the Multi-Ethnic Study of Atherosclerosis. J Am Heart Assoc. 2013;2(6): $\mathrm{e} 000506$.

28. Norris PC, Dennis EA. Omega-3 fatty acids cause dramatic changes in TLR4 and purinergic eicosanoid signaling. Proc Natl Acad Sci US A. 2012;109(22):8517-8522.

29. Morin C, Hiram R, Rousseau E, Blier PU, Fortin S. Docosapentaenoic acid monoacylglyceride reduces inflammation and vascular remodeling in experimental pulmonary hypertension. Am J Physiol Heart Circ Physiol. 2014;307(4):H574-H586.

30. Houghton AM. Mechanistic links between COPD and lung cancer. Nat Rev Cancer. 2013;13(4):233-245.

31. Kelly L, Grehan B, Chiesa AD, et al. The polyunsaturated fatty acids, EPA and DPA exert a protective effect in the hippocampus of the aged rat. Neurobiol Aging. 2011;32(12):.e2311-.e2315. 
32. Yang $\mathrm{S}, \mathrm{Wu} \mathrm{H}$, Zhao J, et al. Feasibility of $8-\mathrm{OHdG}$ formation and hOGG1 induction in PBMCs for assessing oxidative DNA damage in the lung of COPD patients. Respirology. 2014;19(8):1183-1190.

33. Pereira DM, Correia-da-Silva G, Valentao P, Teixeira N, Andrade PB. Anti-inflammatory effect of unsaturated fatty acids and Ergosta-7,22dien-3-ol from Marthasterias glacialis: prevention of CHOP-mediated ER-stress and NF-kappaB activation. PLoS One. 2014;9(2):e88341.

34. Ricciardolo FL, Sterk PJ, Gaston B, Folkerts G. Nitric oxide in health and disease of the respiratory system. Physiol Rev. 2004;84(3):731-765.

35. Ricciardolo FL, Di Stefano A, Sabatini F, Folkerts G. Reactive nitrogen species in the respiratory tract. Eur J Pharmacol. 2006;533(1-3): 240-252.

36. Gabazza EC, Taguchi O, Tamaki S, et al. Role of nitric oxide in airway remodelling. Clin Sci. 2000;98(3):291-294.

37. Prado CM, Leick-Maldonado EA, Yano L, et al. Effects of nitric oxide synthases in chronic allergic airway inflammation and remodeling. Am J Respir Cell Mol Biol. 2006;35(4):457-465.
38. Kougias M, Vardavas CI, Anagnostopoulos N, et al. The acute effect of cigarette smoking on the respiratory function and FENO production among young smokers. Exp Lung Res. 2013;39(8):359-364.

39. Brindicci $\mathrm{C}$, Kharitonov SA, Ito $\mathrm{M}$, et al. Nitric oxide synthase isoenzyme expression and activity in peripheral lung tissue of patients with chronic obstructive pulmonary disease. Am J Respir Crit Care Med. 2010;181(1):21-30.

40. Mozaffarian D, Lemaitre RN, King IB, et al. Plasma phospholipid longchain omega-3 fatty acids and total and cause-specific mortality in older adults: a cohort study. Ann Intern Med. 2013;158(7):515-525.

41. Wilk JB, Tsai MY, Hanson NQ, Gaziano JM, Djousse L. Plasma and dietary omega-3 fatty acids, fish intake, and heart failure risk in the Physicians' Health Study. Am J Clin Nutr. 2012;96(4):882-888.

42. Lemaitre RN, Tanaka T, Tang W, et al. Genetic loci associated with plasma phospholipid n-3 fatty acids: a meta-analysis of genome-wide association studies from the CHARGE Consortium. PLoS Genet. 2011; 7(7):e1002193. 


\section{Supplementary materials Methods}

\section{Baseline dietary assessment}

Cohort members completed the adult English version of validated Harvard Food Frequency Questionnaire (FFQ), a self-administered instrument that includes $\sim 150$ food items distributed within the eight major dietary categories, at the study entry. ${ }^{1}$ The FFQ collects the consumption frequency and serving size of each specified food item during the past 12 months and has good coverage for food items of the US Southwestern style. The FFQ also has open-ended questions that collect use of food items consumed at least once per week but not listed in the eight major dietary categories. The validity of the application of the FFQ in New Mexico Hispanics was further supported by the results from a previous study that compared the energy and nutrient source between elderly Hispanics and non-Hispanic whites (NHWs) in New Mexico and identified no exclusive pattern for consumption of Southwestern regional foods in Hispanics compared to NHWs. ${ }^{2}$ In addition, the estimated consumption of vitamins $\mathrm{A}$ and $\mathrm{C}$ in the current study was highly comparable to the data from a study that itemized all chili-containing traditional
Southwestern foods commonly consumed in New Mexico, suggesting the sufficiency of Harvard FFQ in capturing the chili-derived nutrients. ${ }^{2}$ Furthermore, serum vitamins B12 and $\mathrm{C}$ and folate levels were reported to be significantly lower in Hispanics versus NHWs in a previous study of an elderly New Mexican population. ${ }^{3}$ These three vitamins also showed the ethnic difference in the dietary assessment (not shown). Estimates of daily nutrient intakes are derived by summing over all foods the products of the reported frequency of each food by the amount of nutrient in a specified (or assumed) serving of that food, based primarily on US Department of Agriculture publications. ${ }^{1}$ Individual nutrient intakes were estimated with and without taking supplement use into consideration, and two values were provided. Because the number of nutrients in the output varied over time (from 104 to 254 nutrients from 2005 to 2014), a total of 139 nutrients with $<40 \%$ missing rate was included in this study. Cohort members with extremely low or high total caloric intake were excluded. ${ }^{4}$ None of our participants were removed due to having $>70$ missing items on the FFQ. A total of 1,829 Lovelace Smokers cohort and 508 Veteran Smokers cohort members completed the FFQ that passed the quality check.

Table SI Nutrients associated with FEV /FVC ratio (\%) in the LSC and VSC

\begin{tabular}{|c|c|c|c|c|}
\hline \multirow[t]{2}{*}{ Nutrient (U/day) ${ }^{b}$} & \multicolumn{2}{|c|}{ LSC $(n=I, 829)$} & \multicolumn{2}{|l|}{ VSC $(n=508)$} \\
\hline & $\begin{array}{l}\text { Estimate } \\
\text { (SE) }\end{array}$ & $\overline{\text { FDR }}$ & $\begin{array}{l}\text { Estimate } \\
\text { (SE) }\end{array}$ & $\overline{\text { FDR }}$ \\
\hline \multicolumn{5}{|l|}{ Minerals } \\
\hline Magnesium (174.7 mg) & $0.732(0.396)$ & 0.074 & $2.421(1.024)$ & 0.023 \\
\hline Magnesium (I $44.7 \mathrm{mg})^{c}$ & $\mathrm{I} .256(0.48 \mathrm{I})$ & 0.025 & $2.161(1.063)$ & 0.045 \\
\hline \multicolumn{5}{|l|}{ Vitamins } \\
\hline Total folate intake $(478.6 \mu \mathrm{g})$ & $1.019(0.349)$ & 0.025 & $2.231(0.775)$ & 0.009 \\
\hline Folic acid $(4 \mid \mathrm{I} .0 \mu \mathrm{g})$ & $0.67 \mid(0.325)$ & 0.048 & $1.858(0.706)$ & 0.013 \\
\hline Folate equivalents $(860.5 \mu \mathrm{g})$ & $0.857(0.333)$ & 0.025 & $2.144(0.74 I)$ & 0.009 \\
\hline Niacin (24.8 mg) & $0.374(0.154)$ & 0.025 & $\mathrm{I} .86 \mathrm{I}(0.605)$ & 0.009 \\
\hline Vitamin A $(9,160.2$ IU) & $0.754(0.266)$ & 0.025 & $\mathrm{I} .245(0.534)$ & 0.023 \\
\hline Vitamin D (468.9 IU) & $0.454(0.300)$ & 0.139 & $1.337(0.765)$ & 0.081 \\
\hline \multicolumn{5}{|l|}{ Fatty acids } \\
\hline Eicosenoic fatty acid (I35 mg) & $0.638(0.267)$ & 0.025 & I.54I (0.540) & 0.009 \\
\hline EPA (100 mg) & $0.290(0.121)$ & 0.025 & $0.740(0.263)$ & 0.009 \\
\hline DPA (20 mg) & $0.513(0.202)$ & 0.025 & $1.393(0.405)$ & 0.009 \\
\hline $\mathrm{DHA}(150 \mathrm{mg})$ & $0.456(0.205)$ & 0.034 & $1.319(0.432)$ & 0.009 \\
\hline$E P A+D P A+D H A(310 \mathrm{mg})$ & $0.460(0.192)$ & 0.025 & $1.229(0.405)$ & 0.009 \\
\hline EPA + DHA (290 mg) & $0.452(0.190)$ & 0.025 & $1.207(0.404)$ & 0.009 \\
\hline trans-oleic (1.2 g) & $-0.716(0.559)$ & 0.20 & $-1.847(0.767)$ & 0.022 \\
\hline AOAC fiber $(10.5 \mathrm{~g})$ & $1.075(0.403)$ & 0.025 & $2.018(0.761)$ & 0.013 \\
\hline
\end{tabular}

Notes: EPA, eicosapentaenoic fatty acid 20:5n3; DPA, docosapentaenoic fatty acid 22:5n3; DHA, docosahexaenoic fatty acid 22:6n3; eicosenoic fatty acid 20:In9. alQR is used for calculating the estimate and $95 \% \mathrm{Cl}$. Association analysis in the LSC was conducted based on longitudinal spirometry data using linear mixed effects model with adjustment for important covariates. Association analysis in the VSC was conducted based on baseline spirometry data using linear regression with adjustment for important covariates. ${ }^{b}$ Assessment of total folate intake and folate equivalents includes all sources (ie, natural food, supplements, and fortified foods). Folic acid is from supplements and fortified foods. A total of $38 \%$ study subjects have missing data for trans-oleic fatty acid. 'Estimate of intake without counting supplement.

Abbreviations: FEV $_{1}$, forced expiratory volume in I s; FVC, forced vital capacity; LSC, Lovelace Smokers cohort; VSC, Veteran Smokers cohort; SE, standard error; FDR, false discovery rate; AOAC, the Association of Official Agricultural Chemists; IQR, interquartile range. 
Table S2 The association between long chain unsaturated fatty acid and FEV/FVC decline (\%) in the LSC $(\mathrm{n}=\mathrm{I}, 499)^{\mathrm{a}}$

\begin{tabular}{|c|c|c|c|c|c|}
\hline \multirow[t]{2}{*}{ Nutrient (U/day) } & \multirow{2}{*}{$\begin{array}{l}\text { Time } \\
\text { Estimate } \\
(\mathrm{SE})^{\mathrm{b}}\end{array}$} & \multicolumn{2}{|l|}{ Nutrients } & \multicolumn{2}{|c|}{ Time $\times$ nutrients } \\
\hline & & $\begin{array}{l}\text { Estimate } \\
\text { (SE) }\end{array}$ & $P$-value & $\begin{array}{l}\text { Estimate } \\
\text { (SE) }\end{array}$ & $P$-value \\
\hline Eicosenoic fatty acid (135 mg) & $-0.47(0.02)$ & $-0.048(0.11)$ & 0.67 & $0.032(0.012)$ & 0.0081 \\
\hline EPA (100 mg) & $-0.44(0.01)$ & $0.010(0.052)$ & 0.85 & $0.019(0.006)$ & 0.0030 \\
\hline DPA (20 mg) & $-0.46(0.02)$ & $-0.003(0.087)$ & 0.98 & $0.032(0.011)$ & 0.0028 \\
\hline $\mathrm{DHA}(150 \mathrm{mg})$ & $-0.46(0.02)$ & $-0.037(0.088)$ & 0.67 & $0.031(0.011)$ & 0.0031 \\
\hline $\mathrm{EPA}+\mathrm{DPA}+\mathrm{DHA}(310 \mathrm{mg})$ & $-0.45(0.02)$ & $-0.007(0.083)$ & 0.94 & $0.030(0.010)$ & 0.0028 \\
\hline$E P A+D H A(290$ mg) & $-0.45(0.02)$ & $-0.006(0.082)$ & 0.94 & $0.030(0.010)$ & 0.0028 \\
\hline
\end{tabular}

Notes: EPA, eicosapentaenoic fatty acid 20:5n3; DPA, docosapentaenoic fatty acid 22:5n3; DHA, docosahexaenoic fatty acid 22:6n3; eicosenoic fatty acid 20:In9. alQR is used for calculating the estimate and SE. Association analysis in the LSC was conducted based on longitudinal spirometry data using linear mixed effects model with adjustment for important covariates. ${ }^{b} P<0.0001$.

Abbreviations: $\mathrm{FEV}_{1}$, forced expiratory volume in I s; FVC, forced vital capacity; LSC, Lovelace Smokers cohort; SE, standard error; IQR, interquartile range.

A convenient set of 28 cohort members completed an FFQ for a second time at follow-up visits $\sim 9.4$ years after the study entry. Spearman correlation analysis was conducted for 102 nutrients with no missing data for these 28 cohort members to assess the stability of the dietary pattern over time.

\section{References}

1. Rimm EB, Giovannucci EL, Stampfer MJ, Colditz GA, Litin LB, Willett WC. Reproducibility and validity of an expanded selfadministered semiquantitative food frequency questionnaire among male health professionals. Am J Epidemiol. 1992;135(10):1114-1126. Discussion 1127-1136.
2. Pareo-Tubbeh SL, Romero LJ, Baumgartner RN, Garry PJ, Lindeman RD, Koehler KM. Comparison of energy and nutrient sources of elderly Hispanics and non-Hispanic whites in New Mexico. J Am Diet Assoc. 1999;99(5):572-582.

3. Lindeman RD, Romero LJ, Koehler KM, et al. Serum vitamin B12, C and folate concentrations in the New Mexico elder health survey: correlations with cognitive and affective functions. $J$ Am Coll Nutr. 2000;19(1):68-76.

4. Stidley CA, Picchi MA, Leng S, et al. Multivitamins, folate, and green vegetables protect against gene promoter methylation in the aerodigestive tract of smokers. Cancer Res. 2010;70(2):568-574.
International Journal of COPD

\section{Publish your work in this journal}

The International Journal of COPD is an international, peer-reviewed journal of therapeutics and pharmacology focusing on concise rapid reporting of clinical studies and reviews in COPD. Special focus is given to the pathophysiological processes underlying the disease, intervention programs, patient focused education, and self management protocols.

\section{Dovepress}

This journal is indexed on PubMed Central, MedLine and CAS. The manuscript management system is completely online and includes a very quick and fair peer-review system, which is all easy to use. Visit $\mathrm{http} / / / \mathrm{ww}$.dovepress.com/testimonials.php to read real quotes from published authors. 